\title{
STRUCTURAL MANIFESTATIONS OF ER-STRESS, APOPTPSIS AND NECROSIS IN ENDOTHELIOCYTES OF NEPHRON HEMOCAPILLARIES IN EXPERIMENTAL BURN DISEASE IN RATS UNDER CONDITIONS OF INFUSION OF DIFFERENT DETOXICATION SOLUTIONS
}

\author{
Lakhtadyr T. V.
}

\section{INTRODUCTION}

It is widely accepted that the leading factors of burn disease are endogenous intoxication, dyscirculatory hypoxia and histotoxic ischemia ${ }^{1}$, therefore, in the treatment of burn disease (caused by severe burn injuries), use intravenous detoxification of infusion to prevent the development of severe toxic, hypoxic and reperfusion damage to cells and tissues, the effectiveness of which is the subject of clinical ${ }^{2}$, and experimental studies ${ }^{3}$.

1 Keck, M., Herdon, D. \&Komolz, L.-P. (2009). Pathophysiologyofburns. WienMedWochenschr, 159, 327-336.doi: 10.1136/bmj.328.7453.1427.

${ }^{2}$ Bunn, F., Alderson, P., Hawkins, V. (2012). Colloid solutions for fluid resuscitation. Cochrane Database of Systematic Reviews, 7, 30-34. doi: 10.3389/14651858.CD001319.pub5. Can Ince, Koray Yuruk, Emre Almac. (2007). Hydroxyethyl starch solution and their effect on the microcirculation and tissue oxygenatoin. Transfusion Alternative in Transfusion Medicine, 9(3), 164-172. doi: 10.1111/j.1778-428X.2007.00076.x. Davidson, I.J. (2011). Renal impact of fluid management with colloids: a comparative review. EurJAnaesthesiol, 23(9), 721-738. DOI: 10.1017/S0265021506000639. Groeneveld, A.B., Navickis, R.J. \&Wilkes, M.M. (2011). Update on the comparative safety of colloids: a systematicreview of clinical studies. Ann Surg, 253(3), 470-483. doi: 10.1097/SLA.0b013e318202ff00. Hartog, C.S., Kohl, M., Reinhart, K. (2011). A systematic review of third-generation hydroxyethyl starch (HES 130/0.4) in resuscitation: safety not adequated addressed. Anesth Analg, 16, 635-645. doi: 10.1213/ANE.0b013e31820ad607. Huai-Wu, He (2017). Colloids and the Microcirculation. Anesthesia and Analgesia, 126(5): 1. doi: 10.1213/ANE.0000000000002620. Kruer, R.M., Ensor, C.R. (2012). Colloids in the intensive care unit. Ann J Syst Pharm, 69(19), 1635-1642. https://www.ncbi.nlm.nih.gov/pubmed/22997116. Mohanan, M., Rajan, S., Kesavan, R., Mohamed, Z.U., Ramaiyar, S.K., \& 3umar, L. (2019). Evaluation of renal function with administration of $6 \%$ hydroxyethyl starch and $4 \%$ gelatin in major abdominal surgeries: a pilot study. AnesthEssays Res. 2019 Apr-Jun, 13(2), 219-224. doi:10.4103/aer.AER_25_. Mutter, T.C., Ruth, C.A., \& Dart, A.B., (2013). Hydroxyethyl starch (HES) versus other fluid therapies: effects on kidney function. Cochrane Database Syst Rev. 2013 Jul 23, (7), CD007594, doi: 10.1002/14651858.CD007594.pub3.

${ }^{3}$ Cherkasov, E.V., Gunas, I.V., Chereshnyuk, I.L., \& Lysenko, D.A. (2012). Features of thymus cells cycle in rats after burn lesion of a skin. Ukrainian morphologycal almanac, T. 2, № 3, 109-113. URL : https://dspace.vnmu.edu.ua/123456789/580. Dzevulska, I.V., Kovalchuk, 
It has been recognized ${ }^{4}$ that the main purpose of infusion therapy is not only detoxification but also maintenance of systemic circulation, restoration of tissue perfusion, delivery of oxygen to tissues and optimization of the hemomicrocirculation system, at the level of which oxygen transfer takes place. To this end, different types of crystalloid and colloidal solutions are used. Ongoing discussions on the use of colloidal and crystalloid solutions have now shifted to the debate over the optimal type of colloidal solutions to which hydroxyethyl starch based solutions of different generations are attributed ${ }^{5}$, but even where they continue to be debated about the presence or absence of nephrotoxic effects of hydroxyethyl $\operatorname{starch}^{6}$. This issue is now

O.I., Cherkasov, E.V., Majewskyi, O.Ye., Shevchuk, Yu.G., Pastukhova, V.A., \&Kyselova, T.M. (2018). Influence of lactoproteinum solutoin with sorbitol on dna content of cells of endocrine glands on the background of skin burn in rats. World of medicine and biology, 2(64), 033-039. doi: 10.26724/2079-8334-2018-2-64-33-39. Gavryluk, A.O., Galunko, G.M., Chereshniuk, I.I., Tikholaz, V.O., Cherkasov, E.V., Dzevulska, I.V., \& Kovalchuk O.I. (2018). Indicators cell cycle and DNA fragmentation in cells of small intestine mucosa 14, 21 and 30 days after skin burns on the background of preliminary infusion of solution lactoprotein with sorbitol or HAES-LX5\%. World of Medicine and Biology, 1(63), 104-108. doi: 10.26724/20798334-2017-4-62-104-108. Gunas, I.V., Guminskiy, Yu.I., Ocheretna, N.P., Lysenko, D.A., Kovalchuk, O.I., Dzevulska, I.V., \& Cherkasov E.V. (2018). Indicators cell cycle and dna fragmentation of spleen cells in early terms after thermal burns of skin at the background of introduction $0.9 \% \mathrm{NaCl}$ solution. World of Medicine and Biology, 1(63), 116-120. doi: 10.26.724/2079-8334-2018-1-63-116-120. Kovalchuk, O., Cherkasov, E., Dzevulska. I., Raminsky, R., Korsak, A., \& Sokurenko, L. (2017). Dynamics of morphological changes of rats adenohypophysis in burn disease. Georgian Medical News, 01 Sep 2017(270),104-108. PMID:28972493. Lachtadyr, T.V. (2019). Structural changes of the rat kidney cortical substance in the long-term period after burn injury of the skin under conditions of HAESLX_5\% infusion. Emergency Medicine, 5(100), 96-100. DOI: https://doi.org/10.22141/22240586.5.100.2019.177023. Lachtadyr, T.V., (2017). Structural changes of rats renal cortex in late period of skin burn injury under the conditions of the infusion by lactoprotein with sorbitol. Biomedical and Biosocial Anthropology, № 28, 81-87. Retrieved from https://bbajournal.com/index.php/journal/article/view/237.

${ }^{4}$ Can Ince, Koray Yuruk, Emre Almac. (2007). Hydroxyethyl starch solution and their effect on the microcirculation and tissue oxygenatoin. Transfusion Alternative in Transfusion Medicine, 9(3), 164-172. doi: 10.1111/j.1778-428X.2007.00076.x. HuaiWu, He (2017). Colloids and the Microcirculation. Anesthesia and Analgesia, 126(5): 1. doi: 10.1213/ANE.0000000000002620.

${ }^{5}$ Can Ince, Koray Yuruk, Emre Almac. (2007). Hydroxyethyl starch solution and their effect on the microcirculation and tissue oxygenatoin. Transfusion Alternative in Transfusion Medicine, 9(3), 164-172. doi: 10.1111/j.1778-428X.2007.00076.x.

${ }^{6}$ Can Ince, Koray Yuruk, Emre Almac. (2007). Hydroxyethyl starch solution and their effect on the microcirculation and tissue oxygenatoin. Transfusion Alternative in Transfusion Medicine, 9(3), 164-172. doi: 10.1111/j.1778-428X.2007.00076.x. Groeneveld, A.B., Navickis, R.J. \&Wilkes, M.M. (2011). Update on the comparative safety of colloids: a systematicreview of clinical studies. Ann Surg, 253(3), 470-483. doi: 10.1097/SLA.0b013e318202ff00. Hartog, C.S., Kohl, M., Reinhart, K. (2011). A systematic review of third-generation hydroxyethyl starch (HES 130/0.4) in 
relevant to the study of the effects of various toxicants that cause renal cell death and renal dysfunction ${ }^{7}$.

This issue is now relevant to the study of the effects of various toxicants that cause renal cell death and renal dysfunction ${ }^{8}$. Determination of the mechanisms of reactive and destructive changes of kidney cells under the action of toxicants and factors of various diseases led to the revision of many aspects of the problem of nephrotoxic damage of the kidney and involvement in this process of changes of hemomicrocirculation, stress of endoplasmic reticulum (ER-stress) in cells, necrosis, apoptosis, autophagy ${ }^{9}$. Meanwhile, the study of molecular and cellular manifestations of ER-stress, apoptosis, and necrosis in endothelial cells of nephrons hemocapillaries in burn disease under conditions of infusion of various detoxification solutions has not been the subject of special studies until recently.

The aim of this study is to study the structural manifestations of ERstress, apoptosis and necrosis in endotheliocytes of nephrons hemocapillaries

resuscitation: safety not adequated addressed. Anesth Analg, 16, 635-645. doi: 10.1213/ANE.0b013e31820ad607. Kansir, A.S., Johansen, J.K. \&Pedersen, E.B. (2015). The effect of $6 \%$ hydroxyethyl starch $130 / 0.4$ on renal function, arteriol blood pressure, and vasoactive hormones during radical prostatectomy: a randomized controlled trial. Anesth Analg, 120(3),608-618. doi: 10.1213/ANE.0000000000000596. Mohanan, M., Rajan, S., Kesavan, R., Mohamed, Z.U., Ramaiyar, S.K., \& 3umar, L. (2019). Evaluation of renal function with administration of $6 \%$ hydroxyethyl starch and $4 \%$ gelatin in major abdominal surgeries: a pilot study. AnesthEssays Res. 2019 Apr-Jun, 13(2), 219-224. doi:10.4103/aer.AER_25_. Mutter, T.C., Ruth, C.A., \& Dart, A.B., (2013). Hydroxyethyl starch (HES) versus other fluid therapies: effects on kidney function. Cochrane Database Syst Rev. 2013 Jul 23, (7), CD007594, doi: 10.1002/14651858.CD007594.pub3. Weiskopf, R.B. (2015). Lack nephrotoxicity of hydroxyethyl starch 130/0.4 when used in surgery. Anesthesiology, 123(2), 482-483. doi: 10.1097/ALN.0000000000000719.

Lillie Marie, A., Barnett, B.S., Brain, S., Cummings, Ph, D. (2018). Cellular and Molecular Mechanisms of Kidney Toxicity. Seminars in Nephrology, 39(2), 141-151. DOI: https://doi.org/10.1016/j.semnephrol.2018.12.004.

${ }^{8}$ Lillie Marie, A., Barnett, B.S., Brain, S., Cummings, Ph, D. (2018). Cellular and Molecular Mechanisms of Kidney Toxicity. Seminars in Nephrology, 39(2), 141-151. DOI: https://doi.org/10.1016/j.semnephrol.2018.12.004.

9 Cybulsky, A.V. (2017). Endoplasmatic reticulum stress, the unfolded protein response and autophagy in kidney diseases. Nat Rev Nephrol, 13(11), 681-696. doi: 10.1038/nrneph.2017.129. Gallazzini, V., Pallet, N. (2018). Endoplasmic reticulum stress and kidney dysfunction. Biol Cell, 110(9), 205-216. doi: 10.1111/boc.201800019. Kaushal, G.P., Shan, S.V. (2016). Autophagy in acute kidney injury. Kidney Int, 89(4), 779-791. doi: 10.1016/j.kint.2015.11.021. Lillie Marie, A., Barnett, B.S., Brain, S., Cummings, Ph, D. (2018). Cellular and Molecular Mechanisms of Kidney Toxicity. Seminars in Nephrology, 39(2), 141-151. DOI: https://oi.org/10.1016/ j.semnephrol.2018.12.004. Pickles, S., Vigie, P., \& Youle R.J. (2018). Mitophagy and quality control mechanisms in mitochondrial maintenance. Curr Biol. 2018 Feb 19, 28(4), R170-R185. doi:10.1016/j.cub.2018.01.004. Taniguchi, M., Yoshida, H. (2015). Endoplasmic reticulum stress in kidney function and disease. Curr Opin Nephrol Hypertens, 24(4), 345-350. doi: 10.1097/MNH.0000000000000141. 
in experimental burn disease in rats under the influence of infusion: a typical isotonic crystalloid solution $(0.9 \% \mathrm{NaCl}$ solution $)$, complex protein-salt hyperosmolar solution (lactoprotein with sorbitol) and the recently developed hydroxyethyl starch of the third generation colloidalhyperosmolar solution HAES-LX-5\%.

\section{Modeling of a burn injury}

Materials and methods of research. Structural manifestations of ERstress, apoptosis and necrosis in endothelial cells of nephron hemocapillaries in burn disease in rats under the influence of infusion of various detoxification solutions, namely: $0.9 \% \mathrm{NaCl}$ solution, lactoprotein with sorbitol and HAESLX-5\% was performed 105 white male rats weighing 155-160 grams.

Detention in vivarium and all manipulations with rats were carried out in full compliance with the provisions of the "General Ethical Principles for Animal Experiments", approved by the First National Congress on Bioethics (Kyiv, 2001), with strict compliance with the recommendations of the "European Convention for the Protection of Vertebrate Animals used for experimental and other scientific purposes” (Concil of Europe, Strasburg, 1986).

The experimental rats were divided into 7 groups (15 animals each): group I - intact rats; Group II, III and IV - rats without implementation of burn disease, which was performed separately intravenous infusion of $0.9 \%$ $\mathrm{NaCl}$ solution, lactoprotein with sorbitol and HAES-LX-5\% at a dose of $10 \mathrm{ml} / \mathrm{kg}$; Group V, VI and VII are rats with burn disease, which under the same scheme was an intravenous infusion of the test solutions.

For the simulation of burn disease, an experimental burn skin injury was performed by pressing four heated copper plates (two plates on each side, an area of each $13.86 \mathrm{~cm} 2$ ), held for 6 minutes in water, for 10 seconds to shave the shaved lateral surfaces of the rat. constant $100 \mathrm{C}^{\circ}$. To determine the extent of injury in burn skin injury, we used the severity index of the injury, which takes into account the parameters of the area and depth of burns, as well as the total skin area of the burn. The calculation data show that burn injury of the skin covered 21-23\% of the surface of the animal's body, which is quite sufficient for the formation of burns of II-III degree, the development of burn shock of moderate severity and the initiation of burn disease of the kidneys.

Intravenous infusion of solutions at a dose of $10 \mathrm{ml} / \mathrm{kg}$ was performed for 5 minutes in a vena cava after the catheter was inserted under aseptic conditions through the femoral vein. The course of infusion therapy lasted 7 days (the first intravenous infusion was performed 1 hour after the burn injury of the skin, the subsequent injections were carried out once a day). Burning of the skin, catheterization of the main vessels was performed under anesthesia caused by intraperitoneal injection of propofol at a dose of $60 \mathrm{mg} / \mathrm{kg}$. 
The material was obtained from rats for morphological examination of the kidneys under deep thiopental intraperitoneal anesthesia 14, 21, and 30 days after burn injury. For histological and electron microscopic examinations, the extracted biopsies were processed according to the conventional method. Hemotoxylin-eosin stained histological drugs were examined on a microscope Olympus BX51. Ultra-thin sections were made using LKB-3 ultramicrotome (Sweden), contrasted on copper support meshes with uranyl acetate and lead citrate of Reynolds. Electron microscopic examination was performed using a PEM-125K electron microscope.

\section{Detoxification effect of infusion solutions $n$ the cortical substance of rat kidneys}

The study showed that burn injury of the skin and the resulting burn disease lead to significant structural changes hemocapillaries of the vascular glomeruli (component of the filtration apparatus) and hemocapillaries of the peretubular vascular mesh (component of reabsorption apparatus) of nephrons after 14, 21 and 30 days (in stages of late toxemia and septicotoxemia of burn disease, manifestations of which were largely offset by timely infusion therapy). During this period of time, the process of destruction and structural restructuring in the nephrons of experimental burned rats does not fade but is only modified.

It is established that after 14 days after burn injury of the skin, with the infusion of $0.9 \% \mathrm{NaCl}$ solution (rats of group $\mathrm{V}$ ), manifestations of mosaic reactive and destructive changes of the walls of blood vessels, stroma and parenchyma of the kidney are recorded. The dilatation and / or collapse of the blood-filled and / or hollow lumens of the vessels of the peritubular circulatory mesh and hemocapillaries of the vascular glomerulus were detected. The phenomena of interstitial edema and diapedesis of erythrocytes are observed. The partial destruction of the vascular wall of the hemocapillaries is recorded, as well as the formation of paravasal edema, hemorrhages, lympho-leukocyte infiltrates.

After 21 days of observation in the cortical substance of the kidneys of rats of group $\mathrm{V}$ revealed interstitial edema, which has mainly perivascular localization. Deformation and destruction of the granular endoplasmic reticulum, vacuolization of the cytoplasm and partial detachment of endothelial cells of the peritubular hemocapillaries are observed. Sometimes subtotal or even total destruction of the wall of single peritubular hemocapillaries is followed, followed by the formation of paravasal hemorrhages.

The lumen of most peritubular blood vessels is filled with malignant red blood cells. The presence of peritubular blood vessels with a ruptured wall and paravasal interstitial hemorrhages is combined with the appearance of hemolyzed erythrocytes and cellular detritus in the lumen of the nephron 
tubules with the damaged wall. In the area of hemorrhage among the erythrocytes are the remains of the destroyed cells (Fig. 1), so it is difficult, in most cases, to determine the degree of damage to the wall of the localized peritubular blood vessels in this area.
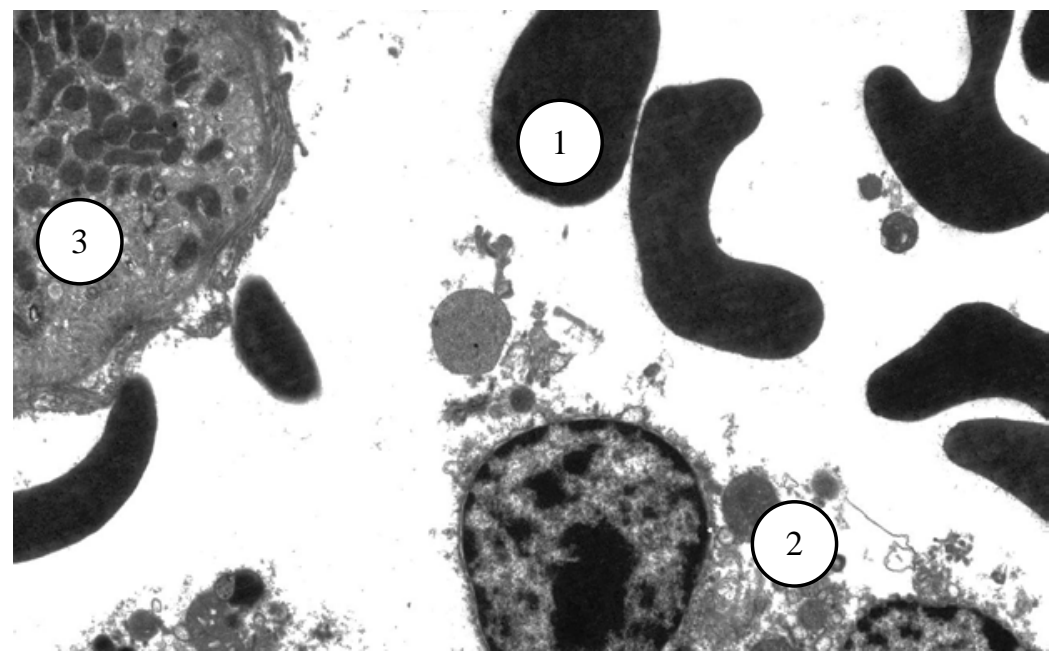

Fig. 1. The area of hemorrhage in the cortical substance of the kidney of the rat after 21 days after burn injury of the skin with the introduction of $0.9 \%$ solution .NaCl. 1 - erythrocyte; 2 - cell detritus; 3 - cytoplasm of nephron tubule epitheliocyte. Electronic micrograph. Coll. 20000

Attention is drawn to the hemocapillaries of the vascular glomerulus, the endothelial coating of which is locally completely disintegrated due to apoptosis (anoikis) of endothelial cells. The lumen of such microvessels is fouled by apoptotic altered endothelial cells that have completely or partially lost contact with the basement membrane. The nucleoplasm and cytoplasm in such apoptotic endothelial cells are condensed, the nuclear membrane is in many places invaginated, chromatin in a state of marginal aggregation (Fig. 2).

Under the conditions of intravenous infusion of lactoprotein with sorbitol (VI group rats), 14 days after the burn skin injury, the hemocapillaries of the peritubular vascular mesh of the nephrons are structurally preserved. The endothelial cells of these hemocapillaries are characterized by the zonation of the cytoplasm, which arises due to the organelle hypertrophy of the protein-synthesizing apparatus. In particular, hypertrophied, long, branched, but prone to parallel placement relative to each other, expanded and filled with small-globular contents of the tubules of granular endoplasmic reticulum are localized in the adjacent to the nucleus, elongated and thickened area of the organelles. The peripheral, refined area of fenestra 
localization is also long and usually contralateral to the nuclear zone of the endothelial cytoplasmic organelles (Fig. 3).

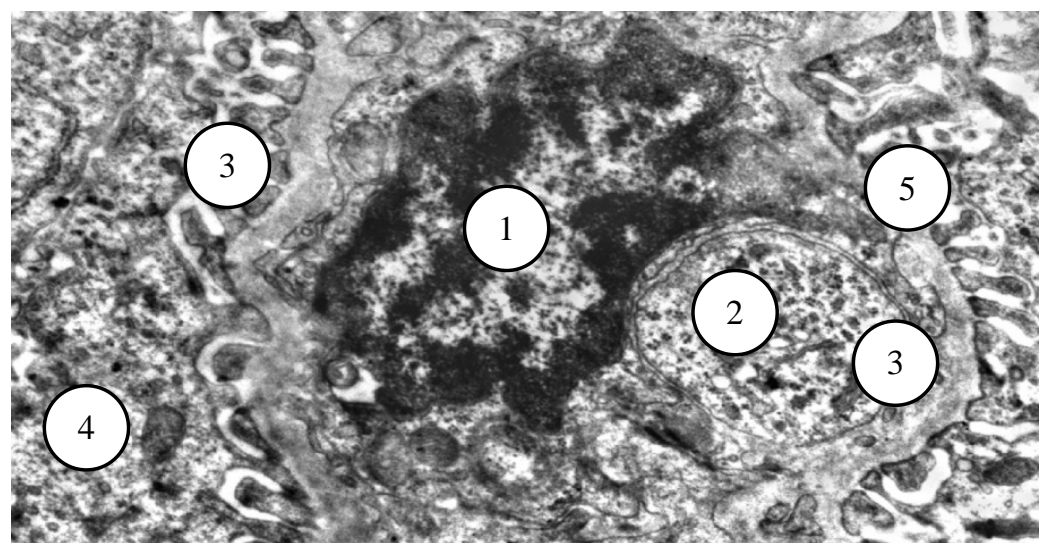

Fig. 2. Hemocapillary of the vascular glomerulus with disintegratedmendothelial coating in the cortical substance of the rat kidney 21 days after burn injury of the skin with the introduction of $0.9 \% \mathrm{NaCl}$ solution. 1 - nucleus of apoptotic endothelial cell; 2 - apoptotic body; 3 - basement membrane; 4 - cytotrachea; 5 - podocyte cytopodia. Electronic micrograph Coll. 35000

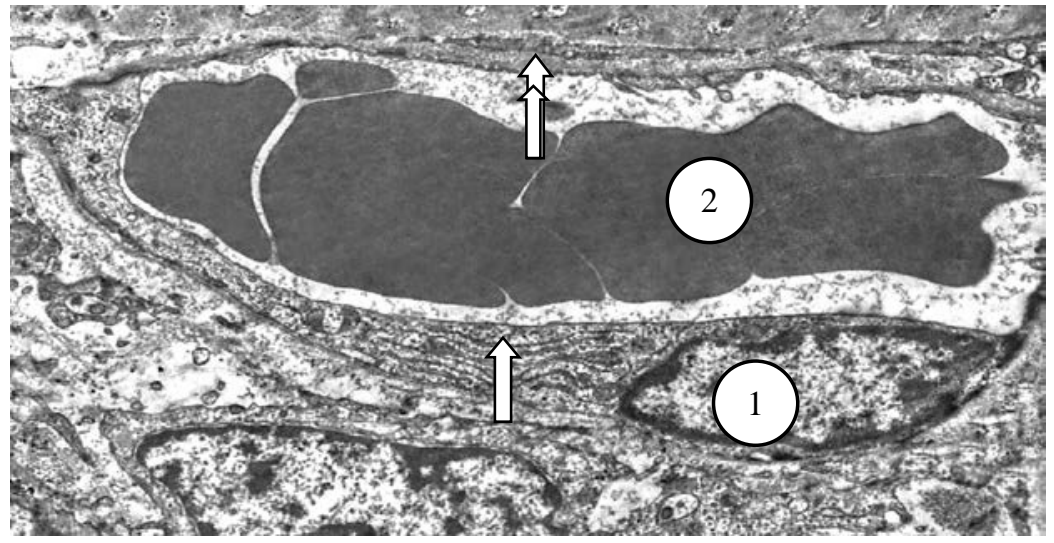

Fig. 3. Hypertrophy of the parallel tubules of the granular endoplasmic reticulum (marked by a single arrow) in the cytoplasm of the endothelial cell of the peritubular vascular mesh capillary in the cortical substance of the rat kidney 14 days after burn injury under conditions of lactation. The double arrow indicates the localization zone of the fenestra in the endothelial cell. 1 - endothelial cell nucleus; 2 - sweetened erythrocytes in the vascular lumen. Electronic micrograph. Coll. 10000 
Electron microscopic examination of the cortical substance of kidneys of animals of group VI 14 days after burn injury of the skin showed that changes in all components of the filtration barrier occur in the kidney cbodyes, but they are less pronounced than in rats, which were administered $0.9 \% \mathrm{NaCl}$ solution. The enlargement of the lumens of hemocapillaries of the vascular glomerulus and their moderate blood flow were noted. In the nuclear zone, the cytoplasm of endothelial cells looks swollen, vacuolated and enlightened, but a clear fenestration of the cytoplasmic regions remains.

In some peritubular areas (Fig. 4.), signs of interstitial edema (in the form of enlightenment of the main amorphous substance) are noted, as well as intracellular edema, autophagic changes, vacuolation, necrosis of the interstitial cells and individual endothelial cells. Vacualization and intracellular edema of hemocapillary endothelial cells is also observed without concomitant signs of perivascular edema and is the result of the vacuolar transformation of the tubules of the granular endoplasmic reticulum, whose membranes lose their attached ribosomes. This is combined with manifestations of hemomicrocirculatory disorders.

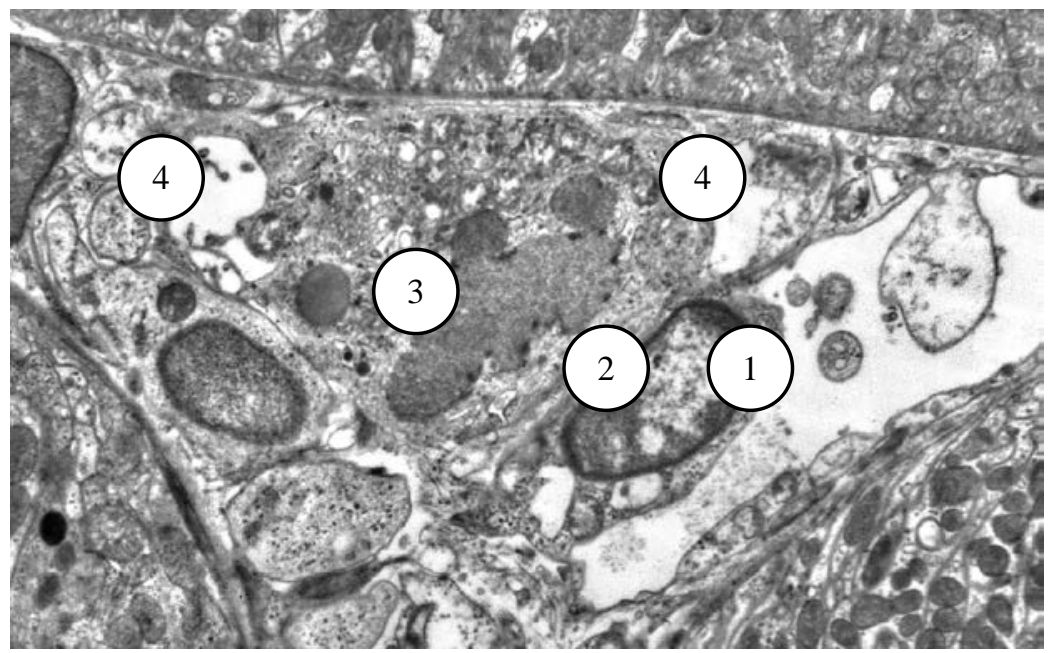

Fig. 4. Intracellular edema and vacuolation of endothelial cells of the peritubular hemocapillary in the cortical substance of the rat kidney 21 days after burn injury of the skin under the conditions of the introduction of lactoprotein with sorbitol.1 - lumen of the peritubular hemocapillary; 2 - nucleus of vacuolated endothelial cell; 3 - the nucleus of the interstitial cell with signs of staged microautophagy; 4 - large autophagic vacuole. Electronic micrograph. Coll. 25000 
The results of the morphological study of the structural components of the crustal substance of the kidneys 30 days after burn injury of the skin of group VI, indicate their high safety. Perivascular edema is insignificant, hemocapillaries of the peritubular mesh are partially dilated and filled with blood. In the cortical substance there are hypertrophied renal little bodies, some have small sizes. The hemocapillaries of the vascular glomerulus in the enlarged kidney bodyes are located tightly and filled with blood. Apoptotic (anoikotic) changes of endothelial cells are noted in the hemocapillaries of vascular glomeruli, but most of the renal little bodies in ultrastructure are similar to those in the kidney of control rats.

Morphological examination of the kidneys of Group VII rats at 14 and 21 days after burn injury of the skin showed that the introduction of HAESLX-5\% solution prevents the development of destructive changes in nephrons.

21 days after burn injury in the kidney of ratsVII group, the lumen of the hemocapillaries of the vascular glomerulus is predominantly enlarged; sometimes it is filled with remnants of cellular detritus. The wall of peritubular hemocapillaries is well preserved and their lumen is usually widened (Fig. 5). The endothelial cells of the hemocapillaries are characterized by the presence of structural features of increased synthetic activity, as evidenced by the presence of mitochondria with well-preserved matrix and crystas, enlarged tubules of granular endoplasmic reticulum and cisterns of the Golgi complex, a considerable number of ribosomes and polysoms. Fenesters and pinocytotic vesicles involved in transendothelial transport of substances almost completely fill the peripheral compartments of endothelial cells (that is, endothelial cells of peritubular hemocapillaries show signs of increased functional activity).

Morphological study of the kidneys of group VII rats with burn skin injury under the conditions of administration of HAES-LX-5\% after 30 days of the experiment allowed sometimes to detect areas of cortex substance that do not differ from those in control (without burn) animals. Cytoplasm of endothelial cells gemo-capillaries of the peretubular vascular mesh and vascular glomeruli of moderate electron density. No signs of swelling or separation of cytoplasmic parts into the lumen of the hemocapillary were detected. The prevalence and relative location of mitochondria, ribosomes, polys, tubules of granular endoplasmic reticulum and Golgi complex testify to their coordinated functioning.

Summarizing the findings, it should be noted that we have studied and compared the effects of different infusion solutions on the structure of endothelial cells of nephrons hemocapillaries of rats with burn disease: a typical crystalloid and hyperosmolar colloidal solutions. Structural changes of hemocapillaries that ensure the functioning of the filtration and reabsorption apparatus of the kidneys under these conditions differed in the severity of the 
destructive and reparative processes (which is a manifestation of the protective and therapeutic effects of solutions). The success of the positive effects of infusion solutions is largely determined not only by their osmolarity, but also by the physicochemical characteristics of their components (which was planned when designing these drugs by the developers).

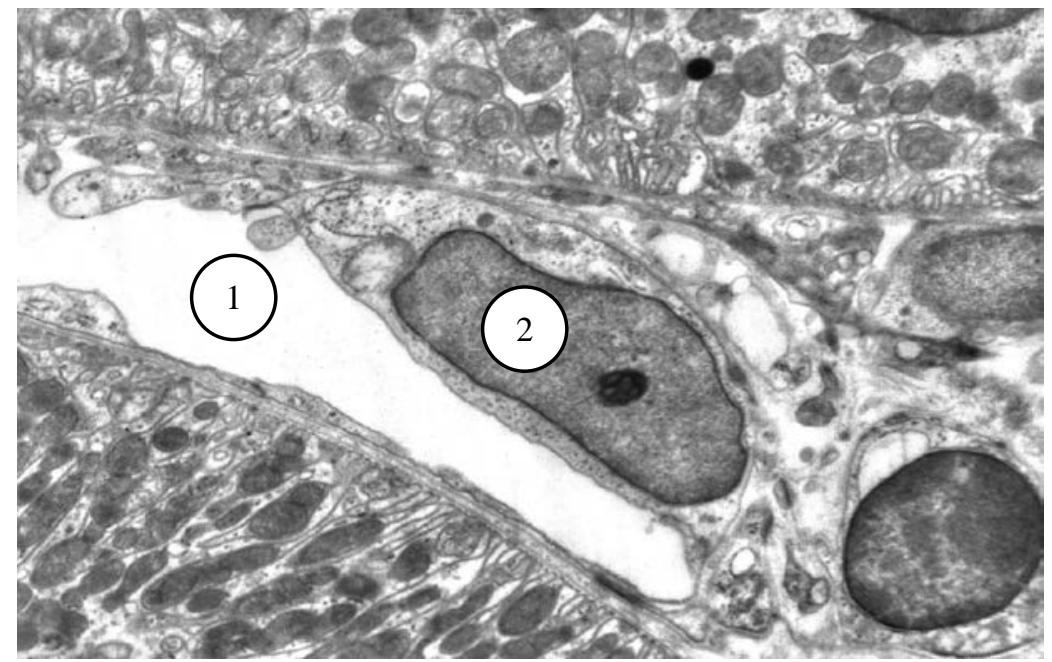

Fig. 5. Good preservation of the peritubular hemocapillary wall structures and adjacent sections of the nephron canal wall in the cortical substance of the rat kidney 21 days after burn injury of the skin under the conditions of HAES-LX-5\% administration. 1 - the lumen of the peritubular hemocapillary; 2 - the nucleus of the endothelial cell. Electronic micrograph. Coll. 15000

Due to hyperosmolarity, lactoprotein with sorbitol and HAES-LX-5\% have been shown to cause excess fluid (resulting from an inflammatory response to burn skin injury) from the intracellular sector to the vascular bed. It improves hemomicrocirculation and renal perfusion, which is morphologically attested and histo-physiologically substantiated when performing this study.

The peculiarity of lactoprotein with sorbitol and HAES-LX-5\% is determined by the presence of both colloidal and crystalloid components in their composition. The colloidal portion of lactoprotein with sorbitol is donor albumin. Due to the hyperosmolarity of lactoprotein with sorbitol, which is 1020 mosmol / l, there is a dehydration of tissues, movement of water into the vascular bed, decrease in blood viscosity, improvement of tissue blood supply. The colloidal component of HAES-LX-5\% is 5\% 
hydroxyethyl starch 130 / 0.4, which belongs to the group of tetrachromal and has an osmolarity of $890 \mathrm{mSmol} / \mathrm{l}$, which is three times the osmolarity of $0.9 \% \mathrm{NaCl}$ solution.

It is clear that in conditions of burn disease, the histo-physiological state of nephrons depends on the dynamics of the renal blood flow rate (which "turns on / off" certain nephrons in a certain order). The rate of renal blood flow depends on changes in central hemodynamics and a whole set of other factors of burn disease ${ }^{10}$. Thus, the revealed mosaic of structural reactions of endothelial cells of the hemocapillaries of the crustal substance of the kidneys is due both to the features of the coordinated functioning of the nephron system in the normal state, and to the discoordination of its loading under conditions of burn disease and infusion of applied dintoxication solutions.

Studies have shown the absolute positive benefits of intravenous infusion of colloidal-hyperosmolar solutions over infusion of isotonic solution, which is $0.9 \% \mathrm{NaCl}$ solution. There are also differences in the influence on the structure of the bark substance of the kidneys of burned rats of lactoprotein with sorbitol and HAES-LX-5\%.

The most vulnerable organelle of endothelial cells of nephron hemocapillaries in burn disease and detoxification therapy is found to be a granular endoplasmic reticulum. According to current ideas ${ }^{11}$, the granular endoplasmic reticulum is a membrane network that extends throughout the cytoplasm of the cell and is adjacent to the nuclear envelope. It is a site of protein synthesis and transport, its assembly and folding, protein degradation, lipid and steroid synthesis, carbohydrate metabolism and calcium storage. The granular endoplasmic reticulum consists of functional subdomains that have a unique biophysical structure that requires coordination in response to changes in the intracellular environment. Proteins are synthesized in ribosomes that attach to the tubular membranes of the granular endoplasmic reticulum. Once inside the tubules of the granular endoplasmic reticulum, the proteins undergo post-translational modification and acquire their correct three-dimensional shape (collapsed). Excessive increase in protein synthesis can lead to overloading of mechanisms of protein folding in the lumen of the tubules of the granular endoplasmic reticulum, which may result in imbalance of coagulation and accumulation of misfolded (folded) proteins ${ }^{12}$, which causes an enzyme to

10 Keck, M., Herdon, D. \&Komolz, L.-P. (2009). Pathophysiologyofburns. WienMedWochenschr, 159, 327-336.doi: 10.1136/bmj.328.7453.1427.

${ }^{11}$ Dianne, S. Schwarz and Michael, D. Blower. (2016). The endoplasmic reticulum: structure, function and response to cellular signaling. Cell Mol Life Sci, 73, 79-94. doi: 10.1007/s00018-015-2052-6.

12 Adams, C. J., Kopp, M.C., Larburu, N., Nowak, P. R., and Ali, M.M.U. (2019). Structure and Molecular Mechanism of ER Stress Signaling by the Unfolded Protein 
stress and stress. reticulum or ER-stress). Misfolded proteins may either remain in the tubules of the granular endoplasmic reticulum or be involved in an ER-associated degradation pathway (ERAD). The recognition of misfolded proteins (which are toxic to the cell) and the subsequent clearance of these aggregates along the ERAD pathway requires careful monitoring, whose attenuation affects cell function. The result of ER-stress is the development of many diseases, including kidney disease ${ }^{13}$.

Recent kidney studies ${ }^{14}$ have found that acute kidney injury caused by ischemia-reperfusion leads to the accumulation of unfolded and misfolded proteins in the lumen of the tubules of the granular endoplasmic reticulum and of the development of ER-stress. Under these conditions, prolonged ERstress activates the apoptotic cell death pathway, eliminating dysfunctional cells. Acute kidney damage is known to be a clinical condition characterized by kidney damage with rapid decline in renal function, leading to high patient mortality and disease prevalence.

According to M. Yanetall ${ }^{15}$, modulation of ER stress in renal cells can ensure successful implementation of a therapeutic strategy for the treatment of acute renal disease. Acute kidney damage is a major contributor to chronic kidney disease, affecting millions of people worldwide, which is one of the major health care problems ${ }^{16}$. This is why it is now widely accepted that ER stress plays a major role in acute and chronic structural damage to the kidneys, but also promotes cellular adaptation and nephroprotection ${ }^{17}$.

Response Signal Activator IRE1. Front. Mol. Biosci, 6, 11. doi: 10.1111/fmolb.2019. 00011. Walter, P., and Ron, D. (2011). The unfolded protein response: from stresspathway to homeostatic regulation. Science, 334, 1081-1086. doi: 10.1126/science.1209038. Wang, M., and Kaufman, R.J. (2016). Protein misfolding in the endoplasmic reticulum as a conduit to human disease. Nature, 529, 326-335. doi: 10.1038/nature17041.

${ }^{13}$ Cybulsky, A.V. (2017). Endoplasmatic reticulum stress, the unfolded protein response and autophagy in kidney diseases. Nat Rev Nephrol, 13(11), 681-696. doi: 10.1038/nrneph.2017.129. Taniguchi, M., Yoshida, H. (2015). Endoplasmic reticulum stress in kidney function and disease. Curr Opin Nephrol Hypertens, 24(4), 345-350. doi: 10.1097/MNH.0000000000000141.

${ }^{14}$ Yan, M., Sho, S., Guo, C., Tang, C., Dong, Z. (2018). Endoplazmic reticulum stress in ischemic and nephrotoxic acute kidney injury. AnnMed, 50(5), 381-390. doi: 10.1080/07853890.2018.1489142.

${ }^{15}$ Yan, M., Sho, S., Guo, C., Tang, C., Dong, Z. (2018). Endoplazmic reticulum stress in ischemic and nephrotoxic acute kidney injury. AnnMed, 50(5), 381-390. doi: 10.1080/07853890.2018.1489142.

${ }^{16}$ Yan, M., Sho, S., Guo, C., Tang, C., Dong, Z. (2018). Endoplazmic reticulum stress in ischemic and nephrotoxic acute kidney injury. AnnMed, 50(5), 381-390. doi: 10.1080/07853890.2018.1489142.

17 Gallazzini, V., Pallet, N. (2018). Endoplasmic reticulum stress and kidney dysfunction. Biol Cell, 110(9), 205-216. doi: 10.1111/boc.201800019. Yan, M., Sho, S., Guo, C., Tang, C., Dong, Z. (2018). Endoplazmic reticulum stress in ischemic and nephrotoxic acute kidney injury. AnnMed, 50(5), 381-390. doi: 10.1080/ 07853890.2018.1489142. 
The data obtained to date indicate that the structural underpinnings of ER stress are a key challenge for the development of prophylactic and therapeutic strategies for combating burn endogenous intoxication by intravenous infusion of detoxification solutions. In our previous studies ${ }^{18}$, the role of mitochondria in providing reactive rearrangement of epithelial nephron cells in burn disease was established, as well as a role in this process such a phenomenon as mitophagy ${ }^{19}$. The latest (at the time of publication) literature review ${ }^{20}$ on cellular and molecular mechanisms of renal toxicity discusses the role of mitochondria as well as granular endoplasmic reticulum in the signaling pathways of renal cell death, but the role of ER-stress in the regulation death of endothelial cells of kidney hemocapillaries under the action of toxicants remains unaffected by researchers.

It is established that under conditions of development of burn disease (component and factor of which is endogenous intoxication), structural changes of granular endoplasmic reticulum occur in endothelial cells of hemocapillaries of vascular glomeruli and pretubular vascular mesh of nephrons. Under the conditions of the applied detoxification solutions, hypertrophy (expansion of the lumen and the degree of branching) overflows with electron-dense contents of the tubules of the granular endoplasmic reticulum, which, taking into account the scientific literature, indicates the stress of structural mechanisms of protein synthesis and ER-stress creation ${ }^{21}$. The second stage in the development of ER stress is the loss of attachment of most ribosomes to the tubule membranes of the hypertrophied granular endoplasmic reticulum (which may indicate an attempt to restore normal

${ }^{18}$ Lachtadyr, T.V. (2019). Structural changes of the rat kidney cortical substance in the long-term period after burn injury of the skin under conditions of HAES-LX_5\% infusion. Emergency Medicine, 5(100), 96-100. DOI: https://doi.org/10.22141/22240586.5.100.2019.177023. Lachtadyr, T.V., (2017). Structural changes of rats renal cortex in late period of skin burn injury under the conditions of the infusion by lactoprotein with sorbitol. Biomedical and Biosocial Anthropology, №28, 81-87. Retrieved from https://bba-journal.com/index.php/journal/article/view/237.

${ }_{19}$ Pickles, S., Vigie, P., \& Youle R.J. (2018). Mitophagy and quality control mechanisms in mitochondrial maintenance. Curr Biol. 2018 Feb 19, 28(4), R170-R185. doi:10.1016/j.cub.2018.01.004.

${ }^{20}$ Lillie Marie, A., Barnett, B.S., Brain, S., Cummings, Ph, D. (2018). Cellular and Molecular Mechanisms of Kidney Toxicity. Seminars in Nephrology, 39(2), 141-151. DOI: https://doi.org/10.1016/j.semnephrol.2018.12.004.

${ }^{21}$ Adams, C. J., Kopp, M.C., Larburu, N., Nowak, P.R., andAli, M.M.U. (2019). Structure and Molecular Mechanism of ER Stress Signaling by the Unfolded Protein Response Signal Activator IRE1. Front. Mol. Biosci, 6, 11. doi: 10.1111/ fmolb.2019.00011. Dianne, S. Schwarz and Michael, D. Blower. (2016). The endoplasmic reticulum: structure, function and response to cellular signaling. Cell Mol Life Sci, 73, 7994. doi: 10.1007/s00018-015-2052-6. Walter, P., and Ron, D. (2011). The unfolded protein response: from stresspathway to homeostatic regulation. Science, 334, 1081-1086. doi: 10.1126/science.1209038. 
endothelial cell function by arresting protein translation). Such a scenario of ultrastructural transformation is not a preventer of endothelial cell apoptosis, but a preventer of necrosis. In the worst case scenario of ER stress, the tubules of the granular endoplasmic reticulum are released from the ribosome attached to the vacuoles, which merge with each other. The resulting over-vacuolation of the cytoplasm results in the necrosis of endothelial cells, which is caused by both a deficiency of correctly folded proteins and an excess of misfolded proteins that exert a cytotoxic effect.

The effectiveness of the detoxification solutions used was evaluated with regard to the variants of the course of ER-stress in endothelial cells of rats nephron hemocapillaries with burn disease caused by burn skin injury. Under the conditions of intravenous infusion of colloidal-hyperosmolar solutions (lactoprotein with sorbitol and HAES-LX-5\%), ER-stress is normalized, accompanied by apoptosis changes of endothelial cells, but not accompanied by necrosis of endothelial cells (which, by definition, and prone to unmanaged process). Necrosis of the endothelial cells of the hemocapillaries of the kidneys results in the formation of paravasal hemorrhages and lympho-leukocyte infiltrates, which is evidence of impaired filtration and reabsorption functions of the kidneys, as well as the progress of the inflammatory process in the kidneys. Such structural changes are especially dangerous because, under conditions of burn endogenous intoxication, the detoxification function of the kidneys deteriorates. Nowadays the question of the effectiveness of the prophylactic and therapeutic effect of intravenous infusion of detoxification solutions is actualized ${ }^{22}$ not only by the problem of ischemia-reperfusion of damaged tissues, but also by the effects of various colloidal components of various colloid-hyperosmolar solutions directly on kidney cells (problem of nephrotoxicity or absence of nephrotoxicity of crystalloid and colloidal infusion solutions).

It should be noted that there is a continuing debate in the scientific literature about the presence or absence of nephrotoxic effects of infusion colloid-electrolyte-hyperosmolar solutions based on hydroxyethyl starch of different generation ${ }^{23}$. The data obtained indicate the nephroprotective

\footnotetext{
22 Davidson, I.J. (2011). Renal impact of fluid management with colloids: a comparative review. EurJAnaesthesiol, 23(9), 721-738. DOI:10.1017/ S0265021506000639. Huai-Wu, He (2017). Colloids and the Microcirculation. Anesthesia and Analgesia, 126(5): 1. doi: 10.1213/ANE.0000000000002620. Kruer, R.M., Ensor, C.R. (2012). Colloids in the intensive care unit. Ann J Syst Pharm, 69(19), 16351642. https://www.ncbi.nlm.nih.gov/pubmed/22997116.

${ }^{23}$ Can Ince, Koray Yuruk, Emre Almac. (2007). Hydroxyethyl starch solution and their effect on the microcirculation and tissue oxygenatoin. Transfusion Alternative in Transfusion Medicine, 9(3), 164-172. doi: 10.1111/j.1778-428X.2007.00076.x. Groeneveld, A.B., Navickis, R.J. \&Wilkes, M.M. (2011). Update on the comparative
} 
properties of a new (created on the basis of the hydroxyethyl starch of the third generation HES 130 / 0.4) balanced plasma substitute HAES-LX-5\%, which has a cytoprotective effect on the structure of endothelial cells of hemocapillaries of nephron rats with burn disease. These data are consistent with data from other researchers ${ }^{24}[4 ; 8 ; 10 ; 12 ; 18 ; 20 ; 21]$ regarding the

safety of colloids: a systematicreview of clinical studies. Ann Surg, 253(3), 470-483. doi: 10.1097/SLA.0b013e318202ff00. Hartog, C.S., Kohl, M., Reinhart, K. (2011). A systematic review of third-generation hydroxyethyl starch (HES 130/0.4) in resuscitation: safety not adequated addressed. Anesth Analg, 16, 635-645. doi: 10.1213/ANE.0b013e31820ad607. Kansir, A.S., Johansen, J.K. \&Pedersen, E.B. (2015). The effect of $6 \%$ hydroxyethyl starch $130 / 0.4$ on renal function, arteriol blood pressure, and vasoactive hormones during radical prostatectomy: a randomized controlled trial. Anesth Analg, 120(3),608-618. doi: 10.1213/ANE.0000000000000596. Mohanan, M., Rajan, S., Kesavan, R., Mohamed, Z. U., Ramaiyar, S.K., \& 3umar, L. (2019). Evaluation of renal function with administration of $6 \%$ hydroxyethyl starch and $4 \%$ gelatin in major abdominal surgeries: a pilot study. AnesthEssays Res. 2019 Apr-Jun, 13(2), 219-224. doi:10.4103/aer.AER_25_. Mutter, T.C., Ruth, C.A., \& Dart, A.B., (2013). Hydroxyethyl starch (HES) versus other fluid therapies: effects on kidney function. Cochrane Database Syst Rev. 2013 Jul 23, (7), CD007594, doi:10.1002/14651858.CD007594.pub3. Weiskopf, R.B. (2015). Lack nephrotoxicity of hydroxyethyl starch 130/0.4 when used in surgery. Anesthesiology, 123(2), 482-483. doi: 10.1097/ALN.0000000000000719.

${ }^{24}$ Cherkasov, E.V., Gunas, I.V., Chereshnyuk, I.L., \& Lysenko, D.A. (2012). Features of thymus cells cycle in rats after burn lesion of a skin. Ukrainian morphologycal almanac, T. 2, № 3, 109-113. URL : https://dspace.vnmu.edu.ua/123456789/580. Dzevulska, I.V., Kovalchuk, O.I., Cherkasov, E.V., Majewskyi, O.Ye., Shevchuk, Yu.G., Pastukhova, V.A., \&Kyselova, T.M. (2018). Influence of lactoproteinum solutoin with sorbitol on dna content of cells of endocrine glands on the background of skin burn in rats. World of medicine and biology, 2(64), 033-039. doi:10.26724/2079-8334-2018-2-64-3339. Gavryluk, A.O., Galunko, G.M., Chereshniuk, I.I., Tikholaz, V.O., Cherkasov, E.V., Dzevulska, I.V., \& Kovalchuk O.I. (2018). Indicators cell cycle and DNA fragmentation in cells of small intestine mucosa 14, 21 and 30 days after skin burns on the background of preliminary infusion of solution lactoprotein with sorbitol or HAES-LX5\%. World of Medicine and Biology, 1(63), 104-108. doi:10.26724/2079-8334-2017-4-62-104-108. Gunas, I.V., Guminskiy, Yu.I., Ocheretna, N.P., Lysenko, D.A., Kovalchuk, O.I., Dzevulska, I.V., \& Cherkasov E.V. (2018). Indicators cell cycle and dna fragmentation of spleen cells in early terms after thermal burns of skin at the background of introduction $0.9 \% \mathrm{NaCl}$ solution. World of Medicine and Biology, 1(63), 116-120. doi:10.26.724/20798334-2018-1-63-116-120. Kovalchuk, O., Cherkasov, E., Dzevulska. I., Raminsky, R., Korsak, A., \& Sokurenko, L. (2017). Dynamics of morphological changes of rats adenohypophysis in burn disease. Georgian Medical News, 01 Sep 2017(270),104-108. PMID:28972493. Lachtadyr, T.V. (2019). Structural changes of the rat kidney cortical substance in the long-term period after burn injury of the skin under conditions of HAESLX_5\% infusion. Emergency Medicine, 5(100), 96-100. DOI: https://doi.org/10.22141/ 2224-0586.5.100.2019.177023. Lachtadyr, T.V., (2017). Structural changes of rats renal cortex in late period of skin burn injury under the conditions of the infusion by lactoprotein with sorbitol. Biomedical and Biosocial Anthropology, № 28, 81-87. Retrieved from https://bba-journal.com/index.php/journal/article/view/237. 
positive effects of HAES-LX5\% on the structure of functionally different organs of rats with burn skin injury. All this gives reason to agree that the HAES-LX-5\% solution opens new opportunities for the treatment of burn disease. The prospects for further scientific research in this direction are to study the effects of different colloidal infusion solutions on the structure of nephrons in various pathological conditions.

\section{CONCLUSIONS}

Studies have shown the unconditional positive benefits of intravenous infusion of colloid-hyperosmolar solutions over infusion of isotonic solution, which is $0.9 \% \mathrm{NaCl}$ solution.

The most vulnerable organelle of nephron hemocapillary endothelial cells in burn disease and detoxification therapy is a granular endoplasmic reticulum, so an important indication of the effectiveness of the detoxification solutions used is the nature of ER-stress in them. Under the conditions of intravenous infusion of colloidal-hyperosmolar solutions (lactoprotein with sorbitol and HAES-LX-5\%), ER-stress is normalized, accompanied by apoptosis changes of endothelial cells, but not accompanied by necrosis of endothelial cells (which, by definition, and prone to unmanaged process). Necrosis of the endothelial cells of the hemocapillaries of the kidneys results in the formation of paravasal hemorrhages and lympho-leukocyte infiltrates, which is evidence of impaired filtration and reabsorption functions of the kidneys, as well as the progress of the inflammatory process in the kidneys. Such structural changes are particularly dangerous because, under conditions of burn endogenous intoxication, the detoxification function of the kidneys is impaired.

\section{SUMMARY}

Researches of structural manifestations of ER-stress, apoptosis and necrosis in endothelial cells of nephron hemocapillaries in experimental burn disease in rats (caused by burn injury of the skin with an area of $21-23 \%$ of the body surface) demonstrated unconditional protective and treatment of intravenous infusion of colloid solutions over infusion of isotonic solution, which is $0.9 \% \mathrm{NaCl}$ solution. There are also differences impact the structure of endothelial cells of the nephron hemocapillaries burn rats lactoprotein with sorbitol and HAES-LX-5\%.

The most vulnerable organnels of endothelial cells hemocapillaries of nephrons in experimental burn disease and implemented desintoksikation therapy is granular endoplasmic reticulum, therefore, an important evidence of the effectiveness of applied detoxification solutions is the nature of the flow in them is ER-stress. In terms of intravenous infusion of colloidhyperosmolar solutions (lactoprotein with sorbitol and HAES-LX-5\%), the 
normalization of ER-stress, which is accompanied by apoptosis changes of endothelial cells, but not accompanied by necrosis of endothelial cells (which by definition has the character of deprogramming, random and prone to uncontrollable distribution process). The consequence of necrosis of endothelial cells hemocapillaries kidney is the formation parabasalia hemorrhage and lymph leukocyte infiltration, which is evidence of violations of filtration and reabsorbtion renal function and progress of the inflammatory process in the kidneys. Such structural changes are particularly threatening to the development of negative consequences of burn injury because (in terms of the burn of endogenous intoxication), deteriorating detoxification function of the kidneys.

\section{REFERENCES}

1. Adams, C.J., Kopp, M.C., Larburu, N., Nowak, P.R., and Ali, M.M.U. (2019). Structure and Molecular Mechanism of ER Stress Signaling by the Unfolded Protein Response Signal Activator IRE1. Front. Mol. Biosci, 6, 11. doi: 10.1111/fmolb.2019.00011.

2. Bunn, F., Alderson, P., Hawkins, V. (2012). Colloid solutions for fluid resuscitation. Cochrane Database of Systematic Reviews, 7, 30-34. doi: 10.3389/14651858.CD001319.pub5.

3. Can Ince, Koray Yuruk, Emre Almac. (2007). Hydroxyethyl starch solution and their effect on the microcirculation and tissue oxygenatoin. Transfusion Alternative in Transfusion Medicine, 9(3), 164-172. doi: 10.1111/j.1778-428X.2007.00076.x.

4. Cherkasov, E.V., Gunas, I.V., Chereshnyuk, I.L., \& Lysenko, D.A. (2012). Features of thymus cells cycle in rats after burn lesion of a skin. Ukrainian morphologycal almanac, T. 2, № 3, 109-113. URL : https://dspace.vnmu.edu.ua/123456789/580.

5. Cybulsky, A.V. (2017). Endoplasmatic reticulum stress, the unfolded protein response and autophagy in kidney diseases. Nat Rev Nephrol, 13(11), 681-696. doi: 10.1038/nrneph.2017.129.

6. Davidson, I.J. (2011). Renal impact of fluid management with colloids: a comparative review. EurJAnaesthesiol, 23(9), 721-738. DOI:10.1017/S0265021506000639.

7. Dianne, S. Schwarz and Michael, D. Blower. (2016). The endoplasmic reticulum: structure, function and response to cellular signaling. Cell Mol Life Sci, 73, 79-94. doi: 10.1007/s00018-015-2052-6.

8. Dzevulska, I.V., Kovalchuk, O.I., Cherkasov, E.V., Majewskyi, O.Ye., Shevchuk, Yu.G., Pastukhova, V.A., \&Kyselova, T.M. (2018). Influence of lactoproteinum solutoin with sorbitol on dna content of cells of endocrine glands on the background of skin burn in rats. World of medicine and biology, 2(64), 033-039. doi:10.26724/2079-8334-2018-2-64-33-39. 
9. Gallazzini, V., Pallet, N. (2018). Endoplasmic reticulum stress and kidney dysfunction. Biol Cell, 110(9), 205-216. doi: 10.1111/ boc.201800019.

10. Gavryluk, A.O., Galunko, G.M., Chereshniuk, I.I., Tikholaz, V.O., Cherkasov, E.V., Dzevulska, I.V., \& Kovalchuk O.I. (2018). Indicators cell cycle and DNA fragmentation in cells of small intestine mucosa 14, 21 and 30 days after skin burns on the background of preliminary infusion of solution lactoprotein with sorbitol or HAES-LX5\%. World of Medicine and Biology, 1(63), 104-108. doi:10.26724/2079-8334-2017-4-62-104-108.

11. Groeneveld, A.B., Navickis, R.J. \&Wilkes, M.M. (2011). Update on the comparative safety of colloids: a systematicreview of clinical studies. Ann Surg, 253(3), 470-483. doi: 10.1097/SLA.0b013e318202ff00.

12. Gunas, I.V., Guminskiy, Yu.I., Ocheretna, N.P., Lysenko, D.A., Kovalchuk, O.I., Dzevulska, I.V., \& Cherkasov E.V. (2018). Indicators cell cycle and dna fragmentation of spleen cells in early terms after thermal burns of skin at the background of introduction $0.9 \% \mathrm{NaCl}$ solution. World of Medicine and Biology, 1(63), 116-120. doi:10.26.724/2079-8334-2018-163-116-120.

13. Hartog, C.S., Kohl, M., Reinhart, K. (2011). A systematic review of third-generation hydroxyethyl starch (HES 130/0.4) in resuscitation: safety not adequated addressed. Anesth Analg, 16, 635-645. doi: 10.1213/ANE.0b013e31820ad607.

14. Huai-Wu, He (2017). Colloids and the Microcirculation. Anesthesia and Analgesia, 126(5): 1. doi: 10.1213/ANE.0000000000002620.

15. Kansir, A.S., Johansen, J.K. \&Pedersen, E.B. (2015). The effect of $6 \%$ hydroxyethyl starch 130/0.4 on renal function, arteriol blood pressure, and vasoactive hormones during radical prostatectomy: a randomized controlled trial. Anesth Analg, 120(3), 608-618. doi: 10.1213/ANE. 0000000000000596.

16. Kaushal, G.P., Shan, S.V. (2016). Autophagy in acute kidney injury. Kidney Int, 89(4), 779-791. doi: 10.1016/j.kint.2015.11.021.

17. Keck, M., Herdon, D. \&Komolz, L.-P. (2009). Pathophysiologyofburns. WienMedWochenschr, 159, 327-336. doi: 10.1136/ bmj.328.7453.1427.

18. Kovalchuk, O., Cherkasov, E., Dzevulska. I., Raminsky, R., Korsak, A., \& Sokurenko, L. (2017). Dynamics of morphological changes of rats adenohypophysis in burn disease. Georgian Medical News, 01 Sep 2017 (270), 104-108. PMID:28972493.

19. Kruer, R.M., Ensor, C.R. (2012). Colloids in the intensive care unit. Ann J Syst Pharm, 69(19), 1635-1642. https://www.ncbi.nlm.nih.gov/ pubmed/22997116. 
20. Lachtadyr, T.V. (2019). Structural changes of the rat kidney cortical substance in the long-term period after burn injury of the skin under conditions of HAES-LX_5\% infusion. Emergency Medicine, 5(100), 96100. DOI: https://doi.org/10.22141/2224-0586.5.100.2019.177023.

21. Lachtadyr, T.V., (2017). Structural changes of rats renal cortex in late period of skin burn injury under the conditions of the infusion by lactoprotein with sorbitol. Biomedical and Biosocial Anthropology, № 28, 81-87. Retrieved from https://bba-journal.com/index.php/journal/article/ view/237.

22. Lillie Marie, A., Barnett, B.S., Brain, S., Cummings, Ph, D. (2018). Cellular and Molecular Mechanisms of Kidney Toxicity. Seminars in Nephrology, 39(2), 141-151. DOI: https://doi.org/10.1016/j.semnephrol. 2018.12.004.

23. Mohanan, M., Rajan, S., Kesavan, R., Mohamed, Z.U., Ramaiyar, S.K., \& 3umar, L. (2019). Evaluation of renal function with administration of $6 \%$ hydroxyethyl starch and $4 \%$ gelatin in major abdominal surgeries: a pilot study. AnesthEssays Res. 2019 Apr-Jun, 13(2), 219-224. doi:10.4103/aer.AER_25_.

24. Mutter, T.C., Ruth, C.A., \& Dart, A.B., (2013). Hydroxyethyl starch (HES) versus other fluid therapies: effects on kidney function. Cochrane Database Syst Rev. 2013 Jul 23, (7), CD007594, doi:10.1002/ 14651858.CD007594.pub3.

25. Pickles, S., Vigie, P., \& Youle R.J. (2018). Mitophagy and quality control mechanisms in mitochondrial maintenance. Curr Biol. 2018 Feb 19, 28(4), R170-R185. doi:10.1016/j.cub.2018.01.004.

26. Serghio, M.A., Niszczak, J.\&Parry, I. (2016). Oneworldone burn rehabilitation standard. Burns, 42, 5, 1047-1058. doi: 10.1016/j.burns. 2016.04.002.

27. Taniguchi, M., Yoshida, H. (2015). Endoplasmic reticulum stress in kidney function and disease. Curr Opin Nephrol Hypertens, 24(4), 345-350. doi: 10.1097/MNH.0000000000000141.

28. Walter, P., and Ron, D. (2011). The unfolded protein response: from stresspathway to homeostatic regulation. Science, 334, 1081-1086. doi: 10.1126/science.1209038.

29. Wang, M., and Kaufman, R. J. (2016). Protein misfolding in the endoplasmic reticulum as a conduit to human disease. Nature, 529, 326-335. doi: 10.1038/nature17041.

30. Weiskopf, R.B. (2015). Lack nephrotoxicity of hydroxyethyl starch 130/0.4 when used in surgery. Anesthesiology, 123(2), 482-483. doi: 10.1097/ALN.0000000000000719. 
31. Yan, M., Sho, S., Guo, C., Tang, C., Dong, Z. (2018). Endoplazmic reticulum stress in ischemic and nephrotoxic acute kidney injury. AnnMed, 50(5), 381-390. doi: 10.1080/07853890.2018.1489142.

Information about author:

Lakhtadyr T. V.,

Candidate of Medical Sciences, Associate Professor at the Department of Descriptive and Clinical Anatomy Bogomolets National Medical University 13, Taras Shevchenko Boulevard, Kyiv, 01601, Ukraine 